\title{
Vulnerability to COVID-19, prejudice, and support for economic restrictions towards countries with high level of contamination
}

\author{
Constantina Badea ${ }^{1 *}$, Chloé Touzé ${ }^{1}$, Cassandra Gedeon ${ }^{1}$, Jais Adam-Troian ${ }^{2}$, Mihaela Boza ${ }^{3} \&$ \\ Jean-Baptiste Légal ${ }^{1 *}$ \\ ${ }^{1}$ Paris Nanterre University, Nanterre, France \\ ${ }^{2}$ University of Keele, United Kingdom \\ ${ }^{3}$ Alexandru Ioan Cuza University of Iași, Romania
}

Received 28.07.2021; Received revised 08.12.2021; Accepted 15.12.2021

Available online 30.12.2021

\begin{abstract}
Recent research has extensively investigated how the current COVID-19 pandemic can affect intergroup relations. Much less is known about the impact of COVID-19 on economic and trade decisions. Could the intergroup effects of this pandemic shape support for international economic policies? The aim of this study was to examine the support for restrictive economic policies towards countries with very high levels of COVID-19 contamination (China and Italy) during the first lockdown period (March - April 2020). The survey was conducted in Romania $(\mathrm{N}=669)$ and included measures of COVID-19 vulnerability, prejudice, and support for economic restrictive policy (e.g., to reduce international trade; to set higher taxes). Results showed that higher support for restrictive policies toward China was associated with greater perceived vulnerability to COVID-19 and this link was partially mediated by prejudice toward China. In contrast, support for economic restrictive policies toward Italy was greater when perceived vulnerability to COVID-19 was high, but this relationship between variables was not explained by negative attitudes towards Italy. Practical and theoretical implications are discussed.
\end{abstract}

Keywords: vulnerability to COVID-19, prejudice, restrictive economic policies

Address of correspondence: Constantina Badea and Jean-Baptiste Légal, University of Paris Nanterre. Address: 200 Avenue de la République, 92100 Nanterre, France. University of Paris Nanterre. E-mail: constantina.badea@parisnanterre.fr or jlegal@parisnanterre.fr

Acknowledgment: --

\section{Introduction}

Vulnerability to COVID-19 has had a significant impact on international relations at different levels. The spread of COVID-19 around the world has created a sudden shortage of basic supplies needed to protect individuals from contamination and to provide medical care (e.g., masks, gloves, medical devices, drugs). In Europe, this has led national governments to realize the impact of relocating production to Asian countries where labor costs are cheaper. During this time of pandemic crisis, perceptions of overreliance on China - a major producer of products needed to cope with COVID-19 - were high in European countries. Followingly, the lockdown period was an opportunity for economists and politicians to discuss the potential economic restrictions that European countries could impose on Asian countries and especially China (La Tribune, 2020).

While the pandemic context creates favorable conditions for economic restrictions on China, research in social psychology has shown that negative intergroup attitudes can develop as a result of diseases' threats (Kim et al., 2016; Navarrete \& Fessler, 2006).

Social Identity Theory (SIT; Tajfel \& Turner, 1986) shows that to achieve or maintain a positive social identity people favor their in-group and discriminate out-groups. This out-group discrimination appears when one's social identity is salient and when relations with other groups are competitive or conflictual (Abrams \& Hogg, 2010). But also, having a stable group identity is necessary to build meaningful frames of oneself and navigate the social world while maintaining a positive social identity (Hogg, 2007). In a crisis such as a global pandemic caused by a new virus, everything becomes less predictable and stable, and one's group identity can become vulnerable (Abrams et al., 2021). When one's group identity is threatened (here, by an unstable and unpredictable pandemic situation), members will identify more with their in-group but also differentiate themselves more from out-groups (and even more when the out-groups can be identified as a possible origin of the threat), and thus express more prejudice (Kruglanski et al., 2021)

In turn, negative intergroup attitudes are known to influence consumer behavior and support for different economic policies (Klein, 2002). Could part of the speech advocating economic restrictions towards foreign countries during COVID-19 contamination be explained by prejudice? 
Recent evidence does suggest that the effects of COVID19 already extended to individuals' support for restrictive social policies towards threatening out-groups (Zhai \& Du, 2020, Karwowski et al., 2020). In a recent study, Alston et al. (2020) show that UK participants' prior intergroup contact with Chinese individuals predicted their support for purely discriminatory state policies towards Chinese nationals in the UK (e.g., closing down all Chinese restaurants). Yet, no study so far has investigated whether support for economic policies could be similarly shaped by prejudice, catalyzed in the context of a global pandemic like COVID-19. In the present research, we examined the attitudes of Romanian citizens towards an Asian country (China) and towards a European one (Italy), two countries with a high level of contamination before and during the lockdown period (Liu et al., 2020). We will begin by reviewing empirical studies concerning the link between vulnerability to disease and prejudice against outgroups. We will then examine the impact of prejudice on economic attitudes towards other countries. Finally, we will present the current research and hypotheses we have developed.

\section{Vulnerability to diseases and prejudice against out-groups}

From an evolutionary perspective, there is a link between the ancestral adaptive utility of avoiding potentially dangerous encounters with the contemporary tendency to perceive foreigners negatively, by expressing prejudice and discrimination against them (Faulkner et al., 2004; Schaller, 2003). Indeed, in ancestral environments, one adaptive behavior has been the avoidance of individuals who were thought to be carriers of contagious diseases. Individuals from foreign lands were considered as more likely to display customs that favor the transmission of disease (related to hygiene, food preparation, etc.), and to engage in practices that violate rules adopted by in-group members to protect themselves from prevalent pathogens (Faulkner et al., 2004; Schaller, 2003).

Recent research confirms that people feel more vulnerable to disease transmission during an interaction with an out-group member rather than with an in-group member (Greenaway \& Cruwys, 2019; Smith \& Gibson, 2020; Zhai \& $\mathrm{Du}, 2020)$. Even when the risk of infection is potentially the same, individuals perceive more threat when the risk behavior is carried out by a member of the out-group than by a member of the in-group. For example, Cruwys et al. (2020) found that when a person has a cold and leaves a used handkerchief in a shared workplace, participants perceive a higher risk of contamination if that person belongs to an out-group than if he/she belongs to an in-group. Consequently, to protect themselves against diseases that they had not yet developed immunity to, individuals avoid out-group members and therefore exhibit more negative attitudes against them (Navarrete \& Fessler, 2006; Reny \& Barreto, 2020).

Many empirical studies examined the link between perceived vulnerability to diseases and intergroup attitudes. In a recent article, a nationally representative sample of Americans completed a survey, indicating their perceptions of vulnerability to Ebola, and their xenophobic tendencies (Kim et al., 2016). Results showed that the more vulnerable people felt, the more they exhibited prejudice toward populations coming from directly affected regions in West Africa. Research has also shown that COVID-19 threat perceptions were associated with increased negative attitudes towards foreign groups (Sorokowski et al., 2020). Infection avoidance tendency predicted increased exclusionary attitudes towards foreigners in Japan (Yamagata et al., 2020), and increased xenophobic and anti-Syrian immigrant attitudes in Turkey (Adam-Troian \& Bagci, 2020).
Integrated Threat Theory (ITT) considers that threat and fear are predictors of prejudice and that there are four different types of threat that underlie negative evaluations of out-groups: realistic threat, symbolic threat, negative stereotypes and intergroup anxiety (Stephan \& Stephan, 2000). Realistic threats encompass potential dangers to the physical well-being, economic and political power of one's group. The global pandemic of COVID-19 is a realistic threat that can impact the well-being or the power of one's group. To survive (i.e., evolutionary perspectives), to maintain a positive social identity (i.e., Social Identity Theory) and to protect their group's interests, individuals will develop prejudice and discrimination towards threatening out-groups (Gonzalez et al., 2008; Nshom \& Croucher, 2017). Moreover, affective and motivational factors play an important role in intergroup relations (Correnblum \& Stephan, 2001). Indeed, according to ITT, perceptions of threat directly relate with perceptions of vulnerability, which increase expression of prejudice as a way to reduce experienced anxiety (Demirtas-Madran, 2020; Nshom \& Croucher, 2017; Tabri et al., 2020).

Faulkner and collaborators (2004) also examined the extent to which xenophobic attitudes are predicted by selfreported perceptions of vulnerability to disease in general, among Canadians. In their study, participants who perceived themselves to be vulnerable to diseases were more likely to associate foreign people with danger and had less favorable attitudes towards foreigners. Interestingly, the link between vulnerability to diseases and intergroup attitudes was moderated by the perceived familiarity of out-groups. Specifically, perceived vulnerability to disease predicted more xenophobic attitudes towards out-groups that were subjectively perceived as less familiar (e.g., immigrants coming from Africa, Peru, Qatar, and Sri Lanka). In contrast, perceived vulnerability was not related to prejudice against more familiar out-groups (e.g., European immigrants; Faulkner et al., 2004). It is assumed that in our study, Romanian participants perceive Italy in terms of a historical, more familiar, superordinate European in-group while perceiving China as an out-group.

In addition, Chinese can be more associated with the threat of COVID-19, compared to other groups. Indeed, in a recent study, a specific link has been found between anti-Asian attitudes and the fear of the COVID-19, among Americans (Reny $\&$ Barreto, 2020). Authors analyzed the relationship between attitudes toward Asian Americans and toward other American racial groups, and participants' concern about contracting the coronavirus. Results showed that the vulnerability to COVID-19 was related to prejudice against Asians and not against other racial out-groups, meaning the threat was perceived as coming from Asia, where the virus first expanded itself. In line with these previous works, we therefore expect that perceived vulnerability to COVID-19 is more likely to be associated with prejudice against Chinese, perceived as unfamiliar out-group members. Besides, vulnerability to COVID-19 was also associated with increased authoritarianism and national conservatism (Bieber, 2020).

\section{Prejudice and economic attitudes}

Xenophobic attitudes have an important impact on consumers' economic attitudes. People may prefer to buy ingroup rather than out-group products in order to favorize the national economy (Klein, 2002). However, national in-group favoritism is not only explained by material concerns (resource maximization for the in-group). National preference in the economic field is also tied with individuals' motivation to obtain or to maintain a positive national identity. Favorizing domestic production is seen as a way to improve the socio-economic status of one's country in relation to other foreign countries, and, in 
doing so, boosts one's positive evaluations of one's national identity. The COVID-19 pandemic is not only a realistic threat to the health but also to the economic domain. Therefore, COVID-19 crisis caused a "depressive socio-economic environment" (Elias et al., 2021, p. 785), where individuals will favor nationalism and conservatism to maintain a positive social identity. Nationalism and conservatism in times of crisis lead to more support for authoritarian policies (e.g., antiimmigrant policies and exclusionary nationalism; Hartman et al., 2021; Green et al., 2010) even more so towards outgroups perceived as culturally and economically threatening (Duckitt \& Sibley, 2010).

In the same perspective, researchers have examined a general form of prejudice, "consumer ethnocentrism", and its consequences on economic attitudes. Consumer ethnocentrism captures the economic motives for in-group bias, such as the fear that choosing foreign products threatens the national industry and causes high unemployment (Verlegh, 2007; Sharma, 2011). For example, in a study conducted in the United States, consumer ethnocentrism was the dominant factor in choosing between a domestic good and a Japanese good (Klein, 2002): the higher the Americans scored on the ethnocentrism scale, the more they preferred national products.

It is possible that prejudice might influence support for restrictive economic policies towards the two countries (Italy and China). However, prejudice against Chinese in Europe is high (e.g., Mahfud et al., 2016), while attitudes towards Italians are rather positive. This difference in terms of prejudice between Chinese and Italians is explained by the perception of cultural distance (Mahfud et al., 2016). Indeed, perceived cultural distance (e.g., regarding values, religion, language, family, and marriage life, etc.) is associated with stronger feelings of threat (Goto \& Chan, 2005; Mahfud et al., 2018) and is considered as a determinant of intergroup relations and an important factor for negative intergroup attitude (Allport, 1954; Brewer \& Campbell, 1976). Studies have shown that the greater the perceived cultural distance towards a group, the more prejudice individuals will express against it (Mahfud et al., 2016; Mahfud et al., 2018; SchalkSoekar \& Van de Vijver, 2008). When perceiving a high cultural distance toward an out-group, the familiarity will, therefore, be lessened (Goto \& Chan, 2005). According to the association between perceived vulnerability to disease and discrimination (Faulkner et al., 2004), Romanian participants should feel more familiar with Italians, and thus express fewer prejudices than toward the Chinese group.

Furthermore, negative economic attitudes towards China are encouraged by European institutions as a form of protectionism. For example, the report of the European Court of Auditors (September 9, 2020) evaluated Beijing's investments in Europe, over the last decade, at 150 billion euros. The rapporteurs invited European countries to adopt a common strategy and to question the consequences of Chinese takeovers in sectors such as energy, telecoms, or ports, evoking a real "threat" (La Croix, 2020). We predict that participants' prejudice towards China might be higher, and consequently, they might express higher support for restrictive economic policies against China than against Italy.

\section{The present study}

The objective of this research is to examine the support of Romanian citizens for restrictive economic policies towards countries with very high levels of COVID-19 contamination (China and Italy) during the first lockdown period (March April 2020). The survey includes measures of perceived
COVID-19 vulnerability, intergroup prejudice, and support for restrictive economic policy (to reduce international trade; to set higher taxes).

We formulate the following hypotheses: (1) Support for restrictive policies toward the Asian country (China) should be greater when perceived vulnerability to COVID-19 is high and when prejudice toward Chinese people is important. (2) Also, the effect of COVID-19 vulnerability on support for economic restrictions towards China should be mediated by negative intergroup attitudes. (3) Support for economic restrictive policies toward the European country (Italy) should be greater when perceived vulnerability to COVID is high.

\section{Method}

\section{Participants}

The sample consisted of Romanian citizens who voluntarily took part in the study $(N=669, M$ age $=38.3, S D$ age $=12.2,55 \%$ females). Participants completed a survey in Romanian. Questionnaires were translated from English and back translated by native speakers. The survey was distributed online through Qualtrics. Measures are presented below ${ }^{1}$. Data and supplemental materials are publicly accessible on OSF: https://osf.io/w5s92/?view only=242e0264d268431a84ea3e73 $\underline{07 \mathrm{ccfae} 5}$ The procedure meets the European ethical requirements.

\section{Measures}

Perceived vulnerability to COVID-19 risk. Questions were adapted from the Perceived Risk Scale (Napper, et al., 2012; Kim et al., 2016). Three items assessed perceptions of personal risk (e.g., "I feel vulnerable to COVID-19 infection"), three items assessed perceptions of the local community's risk (e.g., "I feel that people in my local community are vulnerable to COVID-19 infection"), and perceptions of risk to the country (e.g., "I feel that my country is vulnerable to outbreak of COVID-19"). We calculated a unique score of perceived vulnerability, higher score indicating greater vulnerability ( $\alpha=.81$; Likert, 7 points).

Prejudice. Participants indicated their feelings towards citizens from two countries (one European country - Italy, and one Asian country - China) by responding to six items from a scale designed to assess prejudice. The measure included four positive feelings (acceptance, sympathy, warmth, liking - all reversed) and 2 negatives feelings (hostility, fear), as used in Stephan et al. (1998; attitudes towards Chinese $\alpha=.70$; attitudes towards Italians $\alpha=.70$; Likert, 7 points). Higher score indicates higher prejudice.

Support for restrictive economic policy. A set of three items measured participants' support for restrictive economic policy for a European country (e.g., "I would like Romania to reduce trade with Italy as much as possible"; "I would like to see higher taxes (customs duties) on products from Italy.", $(\alpha=.80)$ and for an Asian country (e.g., "I would like Romania to reduce trade with China as much as possible"; "I would like to see higher taxes (customs duties) on products from China.", $(\alpha=.80$; all Likert, 7 points). Higher score indicates higher economical restriction

\section{Results}

Descriptive statistics are presented in the Table 1. One sample t-test comparing the means to the median of the scale (4), showed that perceived vulnerability to COVID-19 was high, $t(668)=10.54, p<.001,95 \%$ CI $[.32, .48], d=0.41$. The levels of the other variables was significantly below the median of the 
scale: prejudice against China, $t(668)=9.21, p<.001,95 \% \mathrm{CI}$ $[-.43,-.27], d=0.35$; prejudice against Italy, $t(668)=22.26, p$ $<.001,95 \%$ CI $[-.94,-.77], d=0.86$; support for restrictive economic policies against China, $t(668)=4.33, p<.001$, $95 \%$ CI $[-.24,-.09], d=0.17$; support for restrictive economic policies against Italy, $t(668)=7.36, p<.001,95 \%$ CI [-.36, $.20], d=0.28$. We also note that prejudice towards China highly correlated with prejudice towards Italy, suggesting a form of ethnocentrism. In addition, the more participants supported restrictive economic policies against China, the more they agreed with higher restrictions against Italy.
Paired-samples t-test showed that prejudice against Chinese was significantly higher that prejudice against Italians, $t(668)=12.43, p<.001,95 \% \mathrm{CI}[-.56,-.41], d=$ 0.48 . By the way, support for restrictive economic policies towards China was stronger than support for these type of policies towards Italy, $t(668)=5.56, p<.001,95 \% \mathrm{CI}[-.29$, $-.13], d=0.21$.

Table 1 Mean, Standard Deviation, and Correlations among variables

\begin{tabular}{|c|c|c|c|c|c|}
\hline & $\mathrm{M}(\mathrm{SD})$ & 1 & 2 & 3 & 4 \\
\hline 1. Vulnerability to COVID-19 & $4.59(1.46)$ & & & & \\
\hline 2. Prejudice (China) & $3.64(0.97)$ & $.14 * * *$ & & & \\
\hline 3. Prejudice (Italy) & $3.22(0.91)$ & .02 & $.54 * * *$ & & \\
\hline 4. Support for restrictive economic policies (China) & $3.71(1.71)$ & $.21 * * *$ & $.43 * * *$ & $.28 * * *$ & \\
\hline 5. Support for restrictive economic policies (Italy) & $3.54(1.61)$ & $.18 * * *$ & $.38 * * *$ & $.36 * * *$ & $.88 * * *$ \\
\hline
\end{tabular}

According to our hypotheses, support for restrictive policies toward China should be greater when perceived vulnerability to COVID-19 is high and this link should be mediated by prejudices toward Chinese. Support for restrictive economic policies toward Italy should be greater when perceived vulnerability to COVID is high. In order to test these hypotheses, we conducted regression analysis examining separately support for restrictive economic policy toward China and toward Italy.

\section{Support for restrictive economic policy toward China}

First, we tested whether the impact of perceived vulnerability to COVID-19 on support for restrictive economic policies towards China was mediated by prejudice, using the procedure by Yzerbyt et al., 2018. Simple regression analysis showed that the link between perceived vulnerability and support for restrictive policies was significant, $b=.24, S E=$ $.04, t(667)=5.48, p<.001, \eta_{p}{ }^{2}=0.04$, as was the link between perceived vulnerability to COVID-19 and prejudice, $b=.09$, $S E=.02, t(667)=3.73, p<.001, \eta_{p}{ }^{2}=0.02$. When perceived vulnerability and prejudice were simultaneously included in the regression analysis, the impact of perceived vulnerability to COVID-19 on support for restrictive economic policies diminished, $b=.17, S E=.04, t(666)=4.27, p<.001, \eta_{p}{ }^{2}=$ 0.05 . However, the link between prejudice and support for restrictive policies remained significant, $b=.72, S E=.06$, $t(666)=11.94, p<.001, \eta_{p}{ }^{2}=0.17$. We also tested the indirect effects using PROCESS (Hayes \& Preacher, 2014). Results showed a significant indirect effect by prejudice, $b=.06, \mathrm{SE}=$ $.02,95 \% C I[.02, .11]$.

\section{Support for restrictive economic policy toward Italy}

We hypothesized that perceived vulnerability to COVID-19 would be related to higher support for restrictive economic policy against Italy. We also explored whether the link between these two variables was mediated by prejudice against Italy, as it was the case for China. Simple regression analysis, showed that the impact of perceived vulnerability to COVID-19 on support for restrictive economic policies was significant, $b=.21, S E=.04, t(667)=4.79, p<.001, \eta_{p}{ }^{2}=$ 0.03 . However, the link between perceived vulnerability to COVID-19 and prejudice against Italy was not significant, $b=$ $.01, S E=.04, t(667)=0.66, p=.509, \eta_{p}{ }^{2}=0.001$. Therefore, the conditions were not satisfied to further test the mediation model.

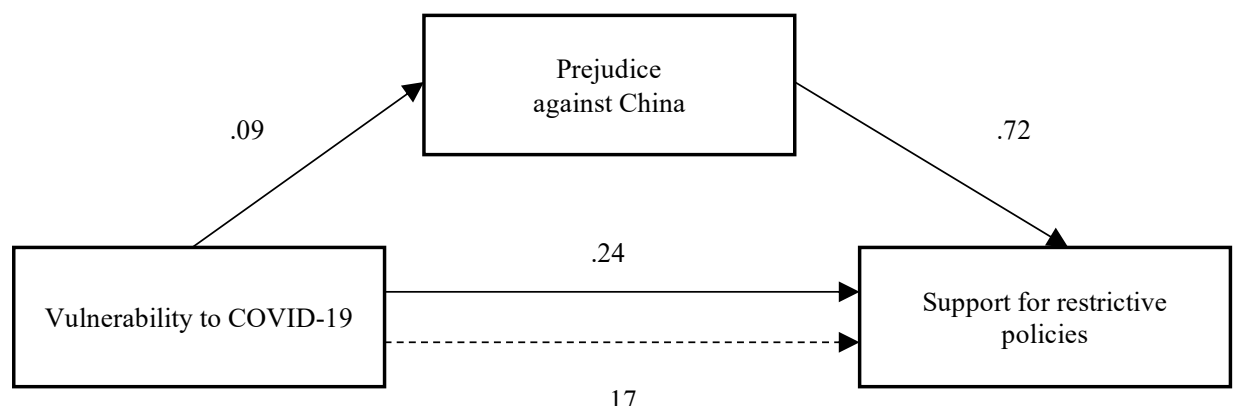

Figure 1. Partial mediation of the link between vulnerability to COVID-19 and support for restrictive economic policies by prejudice against China 


\section{Discussion}

In this study we examined the link between vulnerability to COVID-19, prejudice, and support for economic restrictions towards countries with high levels of contamination. We showed that support for restrictive economic policies toward an Asian country (China) was greater when perceived vulnerability to COVID-19 was higher and when prejudice toward Chinese people was important. The more participants perceived vulnerability to COVID-19, the more they supported restrictive economic policies against China. And the more participants expressed prejudice against Chinese people, the more they wanted their country to impose economic restrictions on this out-group. In addition, the link between perceived vulnerability and support for economic restrictions was partially mediated by prejudice. Results also showed that support for restrictive economic policies toward a European country (Italy) was greater when perceived vulnerability to COVID-19 was higher. Our results are in line with other research showing that ethnocentrism increases when one feels vulnerable to a disease, especially through prejudice and discrimination against foreign groups (Navarrete \& Fessler, 2006; Hodson \& Costello, 2007; Meleady et al., 2021).

This study presents several limitations. First, the data are correlational, preventing any conclusions in terms of cause and effect. It is not clear whether the fear of COVID-19 increases negative intergroup attitudes or vice versa. It is also unclear whether prejudice increases support for restrictive economic policies or the reverse. However, theoretical models suggest that fear of disease in general may increase prejudice towards out-groups (e.g., Integrated Threat Theory; Gonzalez et al., 2008; Kim et al., 2016; Navarrete \& Fessler, 2006), and that prejudice, in turn, influences consumer behavior - in this case support for discriminatory economic policies (Klein et al., 1998; Klein, 2002).

Another limitation is that we only indirectly tested the theoretical assumptions on which we have built our reasoning. Indeed, we did not measure the cultural distance perceived by the Romanians between the ingroup and the Chinese or Italian outgroups. We did not measure the COVID-19 threat from these countries, China and Italy in particular. Although these theoretical assumptions have been empirically proven in empirical studies, future research should directly test the role of perceived threat or cultural distance in the link between disease vulnerability and intergroup attitudes.

Since immemorial times, communities have been implementing strategies to survive in the face of disease. They perceive members of out-groups as carriers of pathogens that should not be allowed to enter the territory of the in-group (Navarrete \& Fessler, 2006). Moreover, individuals' perception of vulnerability to health threat is influenced by group processes (Cruwys et al., 2020). Under conditions of high threat, cooperation and trust are essential within a group to cope with the uncertainty of the situation (Eder et al., 2020; Schaller, 2011). Prejudice and discrimination against outgroups will also be higher in these circumstances (Reny \& Barretto, 2020; Schaller, 2011; Tajfel \& Turner, 1986). For example, Americans showed more xenophobic attitudes toward foreigners during the Ebola epidemic. The more disgust and fear they felt about the disease, the more they called for government interventions to restrict the entry of individuals from West Africa into the US (Kam, 2019).

Measures taken by some governments during the first lockdown period (March-April 2020) illustrate this model of in-group protection, already demonstrated in evolutionary psychology. But the in-group favoritism goes beyond COVID19. Certainly, there are objective reasons for relocating on the national territory the manufacture of products needed to cope with a pandemic.
Indeed, the importance of being self-reliant and reducing dependency on China was discussed in many countries at the onset of this sanitary crisis (Verma \& Naveen, 2021). However, what the present study suggests is that the pandemic is also an opportunity to impose significant restrictions in all sectors on a country that has become an economic threat, which has nothing to do with the COVID-19 crisis (see for instance, La Croix, 2020). It is no longer the fear of COVID-19 that explains the support for economic restrictions but the prejudices that individuals may have towards an out-group.

Beyond the obvious implications regarding the psychological predictors of economic restrictions towards foreign countries, the present results suggest a pathway through which intergroup attitudes and pathogen threat may lead to political preference for authoritarian leaders. These often promote both social and economic conservative policies, especially during societal crises (Sprong et al., 2019). In critical times, people seek support from leaders that are considered stronger, more action-oriented, and possibly more authoritarian than those they usually seek (Abrams et al., 2021; Adam-Troian et al., 2020; Karwowski et al., 2020). In fact, studies showed that health threats are related to higher support for traditionalism and political conservatism (for a meta-analysis, see Terrizzi et al., 2013). Stronger family ties, greater social conservatism and higher ethnic conflicts are observed in regions with a history of higher levels of diseases (Meleady et al., 2021). Therefore, future research should weigh how intergroup and threat perceptions shape preferences for both types of policies (conservatism versus liberalism). If the mechanisms underlying support for economic sanctions overlap with those promoting intergroup conflicts in general, then interventions designed to increase reconciliatory intergroup attitudes could also be used to target support for economic policies (Bar-Tal \& Hameiri, 2020).

It is therefore important to identify the motivations that determine citizens' support for restrictive economic policies beyond the present situation. International cooperation could allow a better management of social and health inequalities and a first step would be to increase the fight against prejudice and discrimination.

\section{References}

Abrams, D., \& Hogg, M. A. (2010). Social identity and selfcategorization (pp. 179-93). The SAGE handbook of prejudice, stereotyping and discrimination.

Abrams, D., Lalot, F., \& Hogg, M. A. (2021). Intergroup and intragroup dimensions of COVID-19: A social identity perspective on social fragmentation and unity. Group Processes \& Intergroup Relations, 24(2), 201-209. https://doi.org/10.1177/1368430220983440

Adam-Troian, J \& Bagci, S.C. (2020). The pathogen paradox: Evidence that perceived COVID-19 threat is associated with both pro-and anti-immigrant attitudes. PsyArXiv. https://doi.org/10.31234/osf.io/948ch

Adam-Troian, J., Bonetto, E., Varet, F., Arciszewski, T., \& Guiller, T. (2020). Pathogen Threat Increases Electoral Success for Conservative Parties: Results from a Natural Experiment with COVID-19 in France. Preprint available at: https://doi.org/10.31234/osf.io/aqkpm

Allport, G. W. (1954). The nature of prejudice (Vol. 537). Reading, MA: Addison-Wesley.

Alston, L., Meleady, R., \& Seger, C. R. (2020). Can past intergroup contact shape support for policies in a pandemic? Processes predicting endorsement of discriminatory Chinese restrictions during the COVID-19 crisis. Group Processes \& Intergroup Relations. https://doi.org/10.1177/1368430220959710

Bar-Tal, D., \& Hameiri, B. (2020). Interventions to change wellanchored attitudes in the context of intergroup conflict. Social and Personality Psychology Compass, 14(7), Article e12534. https://doi.org/10.1111/spc3.12534 
Bieber, F. (2020). Global nationalism in times of the COVID-19 pandemic. Nationalities Papers, 1-13. https://doi.org/10.1017/nps.2020.35

Brewer, M. B., \& Campbell, D. T. (1976). Ethnocentrism and intergroup attitudes: East African evidence. Halsted Press.

Corenblum, B., \& Stephan, W. G. (2001). White fears and native apprehensions: An integrated threat theory approach to intergroup attitudes. Canadian Journal of Behavioural Science/Revue canadienne des sciences du comportement, 33(4), 251. https://doi.org/10.1037/h0087147

Cruwys, T., Greenaway, K. H., Ferris, L. J., Rathbone, J. A., Saeri, A. K., Williams, E., Parker, S. L., Chang, M. X.-L., Croft, N., Bingley, W., \& Grace, L. (2020). When Trust Goes Wrong : A Social Identity Model of Risk Taking. Journal of Personality and Social Psychology, 120(1), 5783. http://dx.doi.org/10.1037/pspi0000243

Cruwys, T., Stevens, M., \& Greenaway, K. H. (2020). A social identity perspective on COVID-19: Health risk is affected by shared group membership. British Journal of Social Psychology, 59(3), 584-593. https://doi.org/10.1111/bjso.12391

Demirtaş-Madran, H. A. (2020). Exploring the motivation behind discrimination and stigmatization related to COVID-19: a social psychological discussion based on the main theoretical explanations. Frontiers in Psychology, 11, 3204. https://doi.org/10.3389/fpsyg.2020.569528

Duckitt, J., \& Sibley, C. G. (2010). Personality, ideology, prejudice, and politics: A dual-process motivational model. Journal of personality, 78(6), 1861-1894. https://doi.org/10.1111/j.1467-6494.2010.00672.x

Eder, S. J., Stefańczyk, M., Pieniak, M., Molina, J. M., Binter, J., Pešout, O., ... \& Steyrl, D. (2020). Pathogenic threat, fear, and perceived vulnerability do not predict ethnocentric orientations during the COVID-19 pandemic in Europe. Under Review.

Elias, A., Ben, J., Mansouri, F., \& Paradies, Y. (2021). Racism and nationalism during and beyond the COVID-19 pandemic. Ethnic and Racial Studies, 44(5), 783-793. https://doi.org/10.1080/01419870.2020.1851382

Faulkner, J., Schaller, M., Park, J. H., \& Duncan, L. A. (2004). Evolved disease-avoidance mechanisms and contemporary xenophobic attitudes. Group Processes \& Intergroup Relations, 7, 333-353. https://doi.org/10.1177/1368430204046142

González, K.V., Verkuyten, M., Weesie, J., \& Poppe, E. (2008). Prejudice towards Muslims in The Netherlands: Testing integrated threat theory. British Journal of Social Psychology, 47, 667-685. https://doi.org/10.1348/014466608X284443

Goto, S. G., \& Chan, D. K. S. (2005). Becoming friends or remaining foes: An empirical test of a causal model of intergroup contact across two cultures. International journal of intercultural relations, 29(2), 197-216. https://doi.org/10.1016/j.ijintrel.2005.05.003

Green, E. G. T., Krings, F., Staerklé, C., Bangerter, A., Clémence, A., Wagner-Egger, P., et al. (2010). Keeping the vermin out: perceived disease threat and ideological orientations as predictors of exclusionary immigration attitudes. J. Community Appl. Soc. Psychol. 20, 299-316. https://doi.org/10.1002/casp.1037

Greenaway, K. H., \& Cruwys, T. (2019). The source model of group threat: Responding to internal and external threats. American Psychologist, 74(2), 218-231. https://doi.org/10.1037/amp0000321

Hartman, T. K., Stocks, T. V., McKay, R., Gibson-Miller, J., Levita, L., Martinez, A. P., ... \& Bentall, R. P. (2021). The authoritarian dynamic during the COVID-19 pandemic: Effects on nationalism and anti-immigrant sentiment. Social Psychological and Personality Science, 12(7), 1274-1285. https://doi.org/10.1177/1948550620978023

Haslam, N., \& Stratemeyer, M. (2016). Recent research on dehumanization. Current Opinion in Psychology, 11, 25-29. https://doi.org/10.1016/j.copsyc.2016.03.009
Hodson, G., \& Costello, K. (2007). Interpersonal disgust, ideological orientations, and dehumanization as predictors of intergroup attitudes. Psychological science, 18(8), 691-698. https://doi.org/10.1111/j.1467-9280.2007.01962.x

Hogg, M. A. (2007). Uncertainty-identity theory. Advances in experimental social psychology, 39, 69-126. https://doi.org/10.1016/S0065-2601(06)39002-8

Institut Montaigne (2020, April 29). Les États face au coronavirus L'archétype italien (The States facing the coronavirus - The Italian archetype). Retrieved from, October, 25 : https://www.institutmontaigne.org/blog/les-etats-face-aucoronavirus-larchetype italien/

Kam, C. D. (2019). Infectious Disease, Disgust, and Imagining the Other. The Journal of Politics, 81(4), 1371-1387. https://doi.org/10.1086/704438

Karwowski, M., Kowal, M., Groyecka, A., Białek, M., Lebuda, I., Sorokowska, A., \& Sorokowski, P. (2020). When in Danger, Turn Right : Does Covid-19 Threat Promote Social Conservatism and Right-Wing Presidential Candidates? Human Ethology, 35(1), 37-48. https://doi.org/10.22330/he/35/037-048

Kim, H. S., Sherman, D. K., \& Updegraff, J. A. (2016). Fear of Ebola: The influence of collectivism on xenophobic threat responses. Psychological Science, 27(7), 935-944. https://doi.org/10.1177/0956797616642596

Klein, J.P. (2002). Us Versus Them, or Us Versus Everyone? Delineating Consumer Aversion to Foreign Goods, Journal of International Business Studies, 33 (2), 345-63. https://doi.org/10.1057/palgrave.jibs.8491020

Klein, J. G., Ettenson, R., \& Morris, M. D. (1998). The animosity model of foreign product purchase: An empirical test in the People's Republic of China. Journal of Marketing, 62, 89-100. https://doi.org/10.1177/002224299806200108

Kteily, N., \& Bruneau, E. (2017). Backlash: The politics and realworld consequences of minority group dehumanization. Personality and Social Psychology Bulletin, 43(1), 87-104. https://doi.org/10.1177/0146167216675334

Kruglanski, A. W., Molinario, E., \& Lemay, E. P. (2021). Coping with COVID-19-induced threats to self. Group Processes \& $\begin{array}{lll}\text { Intergroup } & \text { Relations, } & 24(2),\end{array}$ https://doi.org/10.1177/1368430220982074

La Croix (2020, September, 14). Le commerce entre la Chine et l'Union européenne sous tension (Trade between China and the European Union under strain). Retrieved from, October, 25: https://www.la-croix.com/Economie/Le-commerce-entreChine-lUnion europeenne-tension-2020-09-14-1201113868

La Tribune (2020, Avril 19). Covid-19 : Si la Chine est sciemment responsable, il devrait y avoir des conséquences. (Covid-19: If China is knowingly responsible, there should be consequences.). Retrieved from, October 25: https://www.latribune.fr/economie/international/covid-19-si-lachine-est-sciemment responsable-il-devrait-y-avoir-desconsequences-trump-845537.html

Liu, Y., Gayle, A. A., Wilder-Smith, A., \& Rocklöv, J. (2020). The reproductive number of COVID-19 is higher compared to SARS coronavirus. Journal of travel medicine. https://doi.org/10.1093/itm/taaa021

Mahfud, Y., Badea, C., Guimond, S., Anier, N., \& Ernst-Vintila, A. (2016). Distance culturelle, perception du multiculturalisme et préjugés envers les immigrés en France. L'Année Psychologique, 116, 203-225. https://doi.org/10.4074/S000350331600035X

Mahfud, Y., Badea, C., Verkuyten, M., \& Reynolds, K. (2018). Multiculturalism and attitudes toward immigrants: The impact of perceived cultural distance. Journal of Cross-Cultural Psychology, $\quad 49(6), \quad 945-958$. https://doi.org/10.1177/0022022117730828

Meleady, R., Hodson, G., \& Earle, M. (2021). Person and situation effects in predicting outgroup prejudice and avoidance during the COVID-19 pandemic. Personality and Individual Differences, 172, 110593. https://doi.org/10.1016/j.paid.2020.110593 
Navarrete, C. D., \& Fessler, D. M. (2006). Disease avoidance and ethnocentrism: The effects of disease vulnerability and disgust sensitivity on intergroup attitudes. Evolution and Human Behavior, 27 , 270-282 https://doi.org/10.1016/j.evolhumbehav.2005.12.001

Nshom, E., \& Croucher, S. (2017). Perceived threat and prejudice towards immigrants in Finland: A study among early, middle, and late Finnish adolescents. Journal of International and Intercultural Communication, 10(4), 309-323. https://doi.org/10.1080/17513057.2017.1312489

Passini, S. (2013). What do I think of others in relation to myself? Moral identity and moral inclusion in explaining prejudice. Journal of Community \& Applied Social Psychology, 23, 261269. https://doi.org/10.1002/casp.2117

Prati, F., Moscatelli, S., Pratto, F., \& Rubini, M. (2018). Multiple and counterstereotypic categorization of immigrants: The moderating role of political orientation on interventions to reduce prejudice. Political Psychology, 39, 829-848. https://doi.org/10.1111/pops.12445

Reny, T. T., \& Barreto, M. A. (2020). Xenophobia in the time of pandemic: othering, anti Asian attitudes, and COVID-19. Politics, Groups, and Identities, 1-24. https://doi.org/10.1080/21565503.2020.1769693

Schaller, M. (2003). Ancestral environments and motivated social perception: Goal-like blasts from the evolutionary past. In S. J. Spencer, S. Fein, M. P. Zanna, \& J. M. Olson (Eds.), Motivated social perception: The Ontario Symposium (Vol. 9, pp. 215231). Mahwah, NJ: Erlbaum.

Schaller, M. (2011). The behavioural immune system and the psychology of human sociality. Philosophical Transactions of the Royal Society B: Biological Sciences, 366(1583), 34183426. https://doi.org/10.1098/rstb.2011.0029

Schalk-Soekar, S. R., \& van de Vijver, F. J. (2008). The concept of multiculturalism: A study among Dutch majority members. Journal of Applied Social Psychology, 38(8), 2152-2178. https://doi.org/10.1111/j.1559-1816.2008.00385.x

Smith, L. G. E., \& Gibson, S. (2020). Social psychological theory and research on the novel coronavirus disease (COVID-19) pandemic: Introduction to the rapid response special section. British Journal of Social Psychology, 59(3), 571-583. https://doi.org/10.1111/bjso.12402

Sharma, P. (2011). Country of Origin Effects in Developed and Emerging Markets: Exploring the Contrasting Roles of Materialism and Value Consciousness. Journal of International Business Studies, 42, 285-306. https://doi.org/10.1057/jibs.2010.16

Shoham, A., Davidow, M., Klein, J. G., \& Ruvio, A. (2006). Animosity on the Home Front: The Intifada in Israel and Its Impact on Consumer Behavior. Journal of International Marketing 14, 92-114. https://doi.org/10.1509/jimk.14.3.92

Sorokowski, P., Groyecka, A., Kowal, M., Sorokowska, A., Białek, M., Lebuda, I., Dobrowolska, M., Zdybek, P., \& Karwowski, M. (2020). Can Information about Pandemics Increase Negative Attitudes toward Foreign Groups? A Case of COVID 19 Outbreak. Sustainability, 12(12), 4912. https://doi.org/10.3390/su12124912

Sprong, S., Jetten, J., Wang, Z., Peters, K., Mols, F., Verkuyten, M., ... \& Badea, C. (2019). "Our country needs a strong leader right now": economic inequality enhances the wish for a strong leader. Psychological Science, 30(11), 1625-1637. https://doi.org/10.1177/0956797619875472
Stephan, W. G., \& Stephan, C. W. (2000). An integrated threat theory of prejudice. In S. Oskamp (Ed.), Reducing prejudice and discrimination (pp. 23-45). Lawrence Erlbaum Associates Publishers.

Tabri, N., Hollingshead, S., \& Wohl, M. (2020). Framing COVID-19 as an existential threat predicts anxious arousal and prejudice towards Chinese people. Under Review.

Tajfel, H. T., \& Turner, J. JC (1986). The social identity theory of intergroup behavior. Psychology of Intergroup Relations, 7-24.

Terrizzi Jr, J. A., Shook, N. J., \& McDaniel, M. A. (2013). The behavioral immune system and social conservatism: A metaanalysis. Evolution and Human Behavior, 34(2), 99-108. https://doi.org/10.1016/i.evolhumbehav.2012.10.003

Vaes, J., \& Paladino, M. P. (2010). The uniquely human content of stereotypes. Group Processes \& Intergroup Relations, 13, 23-39. https://doi.org/10.1177/1368430209347331

Valtolina, G. G., Colombo, C., Colombo, M., Fenaroli, V., \& Papavero, G. (2013). The challenge of identity: The experience of children migrating from Romania to Italy with their families. Migrant children in Europe: The Romanian case, 46-83. http://dx.doi.org/10.3233/978-1-61499-205-9-46

Verlegh, P. (2007). Home Country Bias in Product Evaluation: The Complementary Roles of Economic and Socio-Psychological Motives. Journal of International Business Studies, 38 (3), 36173. https://doi.org/10.1057/palgrave.jibs.8400269

Verma, M., \& Naveen, B. R. (2021). COVID-19 Impact on Buying Behaviour. Vikalpa, 46(1), 27-40. https://doi.org/10.1177/02560909211018885

Wolf, E. J., Harrington, K. M., Clark, S. L., \& Miller, M. W. (2013). Sample size requirements for structural equation models: An evaluation of power, bias, and solution propriety. Educational and Psychological Measurement, 73(6), 913-934. https://doi.org/10.1177/0013164413495237

Xia, Y., \& Yang, Y. (2019). RMSEA, CFI, and TLI in structural equation modeling with ordered categorical data: The story they tell depends on the estimation methods. Behavior Research Methods, 51, 409-428. https://doi.org/10.3758/s13428-0181055-2

Yamagata, M., Teraguchi, T., \& Miura, A. (2020). The Relationship between Infection Avoidance Tendency and Exclusionary Attitudes towards Foreigners: A Case Study of the COVID-19 Outbreak in Japan. PsyArXiv. https://doi.org/10.31234/osf.io/x5emj

Yinger, J. (1998). Evidence on discrimination in consumer markets. Journal of Economic perspectives, 12(2), 23-40.

Yzerbyt, V., Muller, D., Batailler, C., \& Judd, C. M. (2018). New recommendations for testing indirect effects in mediational models: The need to report and test component paths. Journal of Personality and Social Psychology, 115(6), 929-943. https://doi.org/10.1037/pspa0000132

Zeugner-Roth, K. P., Žabkar, V., \& Diamantopoulos, A. (2015). Consumer Ethnocentrism, National Identity, and Consumer Cosmopolitanism as Drivers of Consumer Behavior: A Social Identity Theory Perspective. Journal of International Marketing, 23(2), 25-54. https://doi.org/10.1509/jim.14.0038

Zhai, Y., \& Du, X. (2020). Mental health care for international Chinese students affected by the COVID-19 outbreak. The Lancet Psychiatry, 7(4), e22. https://doi.org/10.1016/S2215$\underline{0366(20) 30089-4}$ 